\title{
62. PLIOCENE-PLEISTOCENE MAGNETOSTRATIGRAPHY OF SEDIMENT CORES FROM THE JAPAN SEA $^{1}$
}

\author{
Yozo Hamano, ${ }^{2}$ Klaus A.O. Krumsiek, ${ }^{3}$ Luigi Vigliotti, ${ }^{4}$ and Jobst J.M. Wippern ${ }^{5}$
}

\begin{abstract}
We present the magnetostratigraphic data for Sites 794, 795, 797, 798, and 799 in the Japan Sea. APC cores from these sites record the polarity sequence for the Pliocene-Pleistocene period. The intensity of the magnetization decreases with depth by more than an order of magnitude, and the low intensity samples tend to give scattered directional data. The cause of these phenomena is examined based on the correlation of the intensity with the bulk magnetic susceptibility.
\end{abstract}

\section{INTRODUCTION}

During ODPLegs 127 and 128, six sites (Sites 794, 795, 796, 797, 798, and 799) were drilled in the Japan Sea (see Fig. 1). At each site, the Advanced Hydraulic Piston Corer (APC) was used to drill the upper part of the sedimentary section. This coring method permitted the recovery of hundreds of meters of relatively undisturbed sediments spanning several millions years of time, giving an opportunity for analyzing the sedimentary sequence with high stratigraphic resolution. The pass-through cryogenic magnetometer on board the JOIDES Resolution works well with the APC cores, and enabled us to study the magnetostratigraphy of the sediments in detail. We present results from Sites 794, 795, 797, 798 and 799, in which Site 795 lies in the Japan Basin and other sites are in the Yamato Basin. Cores drilled at Site 796 were mostly disrupted by gas expansion, and it was not possible to resolve a coherent magnetostratigraphy.

Our results were obtained from the shipboard pass-through magnetometer and from the standard paleomagnetic analysis of discrete samples collected during the cruise. These latter measurements supplement the whole-core measurements, especially to delineate the boundaries of zones and subzones and to resolve intervals that were not clearly identified by the shipboard measurements. Questions concerning some magnetic properties of the studied sediments are discussed in the paper by Torii et al. (this volume). Because of the low intensity of magnetization, sediment cores drilled with XCB (extended core barrel) technique do not provide data as reliable as these from the APC cores. This hampered the effort to resolve the magnetostratigraphy older than Gilbert Chron. Even among the APC cores, the low intensity of the samples tends to obscure polarity boundaries. The cause of this low intensity and the unstable magnetizations will be examined later in this paper.

Throughout this paper, the geomagnetic polarity time scale (GPTS) of Berggren et al. (1985) has been adopted for the age of the polarity boundaries.

\section{METHODS}

The archive halves of the core sections were measured with a $2 \mathrm{G}$ pass-through cryogenic magnetometer. Natural remanent magnetization (NRM) measurements were made at $10 \mathrm{~cm}$ intervals before and after the AF demagnetization at several steps up to $15 \mathrm{mT}$, which is the highest AF field allowed by ODP policy. Discrete samples from the working half of the cores were collected by pushing $7 \mathrm{~cm}^{3}$ plastic

'Tamaki, K., Suyehiro, K., Allan, J., McWilliams, M., et al., 1992. Proc. ODP, Sci. Results, 127/128, Pt. 2: College Station, TX (Ocean Drilling Program).

${ }^{2}$ Geophysical Institute, Faculty of Science, University of Tokyo, Tokyo, Japan.

${ }^{3}$ Geologisches Institut, Universitat Köln, Köln, Germany.

${ }_{5}^{4}$ Instituto di Geologia Marina, Consiglio Nazionale D'Recerche, 40127 Bologna, Italy.

${ }^{5}$ Institut Angewandte Geophysik, Universitat München, München, Germany. cubes into the sediments. Because the sediments were characterized by low intensities (generally below $1 \mathrm{~mA} / \mathrm{m}$ ), very few discrete samples from the lower part of the sedimentary column could be studied on board using the spinner magnetometer. Hence, supplementary paleomagnetic studies were made on shore. For Leg 127 samples, the paleomagnetic analyses were made at the paleomagnetic laboratory of the Instituto di Geologia Marina of Bologna and the Institut fur Geophysik of München. Measurements were carried out at IGM using a Jelinek Jr-4 spinner magnetometer while a cryogenic magnetometer was used at IG. All the samples were AF demagnetized in $5-13$ steps, with the highest peak-field ranging between 20 and $100 \mathrm{mT}$, but generally not exceeding $50 \mathrm{mT}$ because of the low coercivity of the sediments.

\section{RESULTS}

In general, $15 \mathrm{mT}$ AF treatment was sufficient to isolate the characteristic remanent magnetization (ChRM) of the sediment. Examples of progressive AF demagnetization behaviors are shown in Figure 2. It can be seen that the NRM is not always stable with respect to the alternating field. As is evident from the figures, the low intensity samples tend to exhibit an unstable result. Figure 3 summarizes the polarity records of Sites $794,795,797,798$, and 799 . The reliable magnetostratigraphic data are confined within the upper several hundred meters of the sedimentary section cored by the APC technique. The depths and the ages of the major polarity boundaries for each site are given in Table 1. In the following, results from each site are discussed separately.

\section{SITE 794}

Site 794 is located at $40^{\circ} 11^{\prime} \mathrm{N}, 138^{\circ} 13^{\prime} \mathrm{E}$ in the northern Yamato Basin. Fifteen APC cores and 22 XPC cores were drilled in Hole 794A to a depth of $351.3 \mathrm{~m}$ below seafloor ( $\mathrm{mbsf}$ ). The stratigraphic section consists mostly of fine-grained hemipelagic sediments of Quaternary to late/middle Miocene age. Quaternary-late Pliocene clay and silty clay with common thin ash layers (Unit 1) overlie diatom ooze and clay (Unit 2).

A nearly continuous magnetostratigraphic record, from Quaternary to the base of Pliocene, was obtained from the whole-core measurements of the core drilled with APC technique. XCB cores measurements gave inconsistent results especially for the weakly magnetized samples. Shore-based measurements of 113 discrete samples confirmed the polarity pattern obtained onboard for the upper $150 \mathrm{~m}$ of the sedimentary section, but did not help to resolve the magnetostratigraphy below this depth.

The intensity of the NRM is generally below $1 \mathrm{~mA} / \mathrm{m}$ with the higher values in the upper part of the section. Below $150 \mathrm{~m}$ sub-bottom depth, the intensity decays to $10^{-2} \mathrm{~mA} / \mathrm{m}$, which is in the noise level of the 


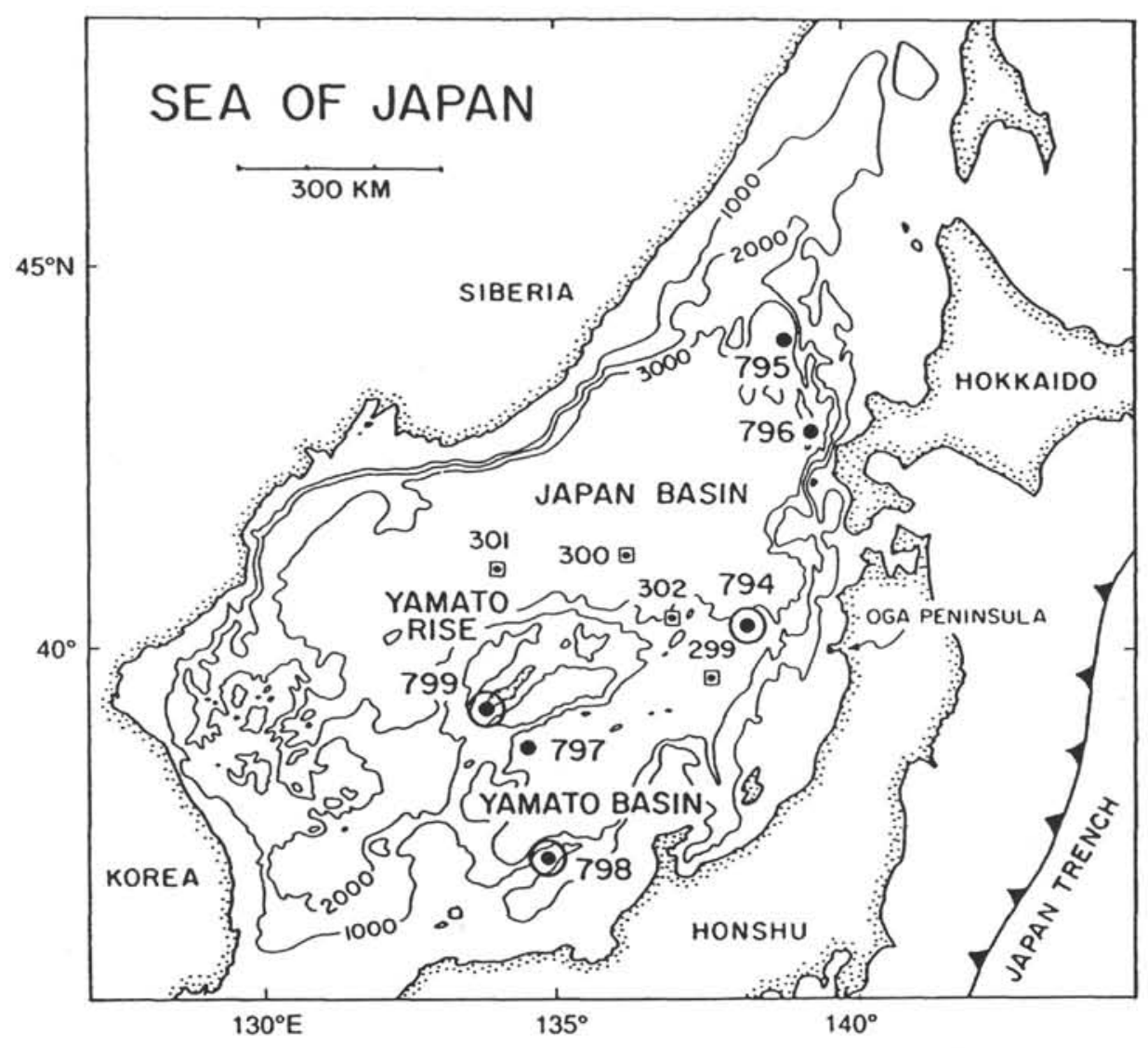

Figure 1. Location map of the Japan Sea drilling sites during ODP Legs 127 and 128.

magnetometer. This weak magnetization hampered definition of a coherent magnetostratigraphy at the deeper parts of the sedimentary section.

Progressive AF demagnetization of sediments from Hole 794A typically indicates one component of magnetization; very few samples possess secondary components, and these can be removed by AF cleaning (Fig. 2). Interpretation of the data from the APC cores drilled at Site 794 in terms of magnetic polarity is straightforward, and the determined polarity pattern can be readily correlated to the GPTS as shown in Figure 3. Nearly all the chrons and subchrons existing in the Pleistocene to Pliocene GPTS can be correlated with the polarity zones in cores from Site 794. The Olduvai subchron was recovered in Core $127-794 \mathrm{~A}-7 \mathrm{H}$ from 54.6 to $58.8 \mathrm{mbsf}$, and its lower boundary is characterized by an abrupt decrease in NRM intensity of the sediments, the meaning of which is not understood. Sedimentological evidence does not show any indication of a possible hiatus.

Some boundaries between normal and reversed polarity such as the Matuyama/Gauss or the Gauss/Gilbert chrons are sharp and could be identified in a restricted interval of about $20 \mathrm{~cm}$. In contrast, the Brunhes/Matuyama boundary is ambiguous with the clear appearance of reversed polarity occurring at $27.15 \mathrm{mbsf}$, beneath several meters characterized by scattered directions of NRM (Fig. 4). It is not easy to determine whether the observed directions are a record of the geomagnetic field or the result of diagenetic processes which have affected the NRM. Recently, multiple reversals of the magnetic field at the Brunhes/Matuyama boundary have been interpreted by Okada and Niitsuma (1989) in a section of the Bôso Peninsula in Japan. However, this section is characterized by an extremely high sedimentation rate which allows examination of a very detailed record of the transitional field that cannot be made for the present cores. Moreover, processes of remagnetization were clearly recognized at this boundary at Site 797, also in the Yamato Basin. This apparent field behavior during the Brunhes/Matuyama polarity transition is discussed more completely below.

\section{SITE 795}

Site 795 is located at $40^{\circ} 98^{\prime} \mathrm{N}, 138^{\circ} 96^{\prime} \mathrm{E}$ in the northernmost Japan Basin. About $352 \mathrm{~m}$ of sediments were drilled by 19 APC cores and $19 \mathrm{XCB}$ cores from Hole 795A. The section consists of three lithostratigraphic units, but only the clay and silty clay of Unit 1 recovered with the first 11 APC cores (0-104.3 mbsf) exhibited a stable magnetic record. Correlation with the GPTS indicates that this interval spans the entire Quaternary period with the bottom of the Olduvai subchron occurring in Section 2 of Core $127-795 \mathrm{~A}-11 \mathrm{H}$. Further downcore, the results from the diatomaceous ooze of Unit 2 are characterized by scattered directions of NRM until the middle of Section 4 of Core 127-795A-15H (138 mbsf). Between 130 and 172 mbsf, a normal polarity zone occurs. AF demagnetization of discrete samples indicated that this normal interval may continue down to 239 mbsf. Sediments from Core 127-795A-12H through Core 127-795A-15H exhibited lower coercivity and instability with respect to the AF cleaning. Moreover a secondary component could not be removed before the NRM decreased to the range of the noise level of the magnetometer. With the caution that reverse polarity NRM could be overprinted by remagnetization, it is possible that the normal polarity starting at 138 mbsf marks the boundary between the Matuyama and Gauss Chrons. The last appearance datum (LAD) of $N$. kamtschatica at $151.9 \mathrm{mbsf}$ (2.6 Ma) appear to support this interpretation. It is possible that the Gauss Chron spans the entire interval between 138 and 239 mbsf.

The NRM intensity is weak and only in the upper $40 \mathrm{~m}$ of the section exceeded values of $10 \mathrm{~mA} / \mathrm{m}$. At the depth of about $100 \mathrm{mbsf}$ 

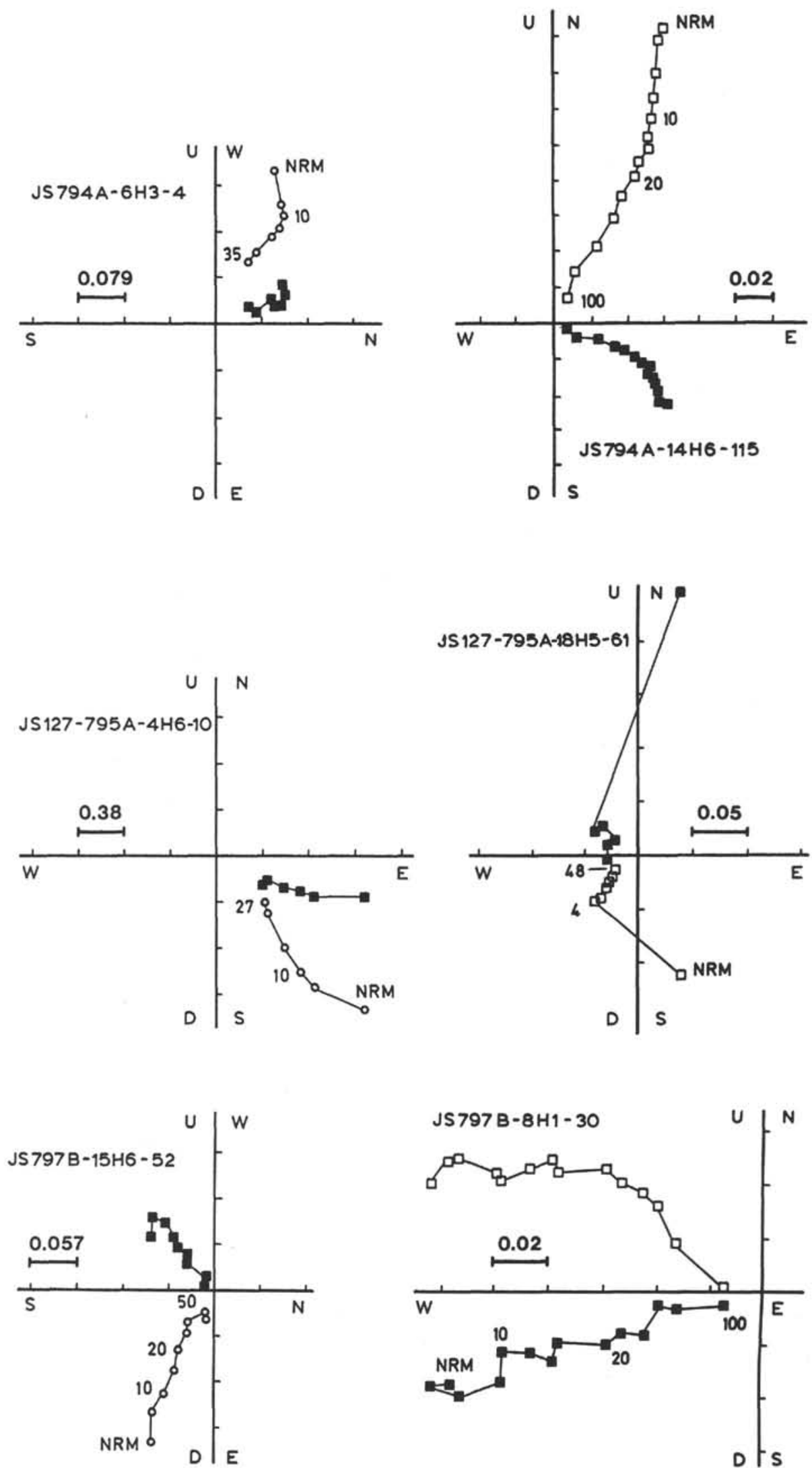

Figure 2. Zijderveld plot of the demagnetization curves for some pilot samples. Closed (open) squares for horizontal (vertical) plane. Scales shown in each plot are in $10^{-3} \mathrm{~A} / \mathrm{m}$ and the numbers at marks indicate the demagnetization field in unit of $\mathrm{mT}$. 


\section{Magnetic polarity time scale}

(after Berggren et al.,1985)

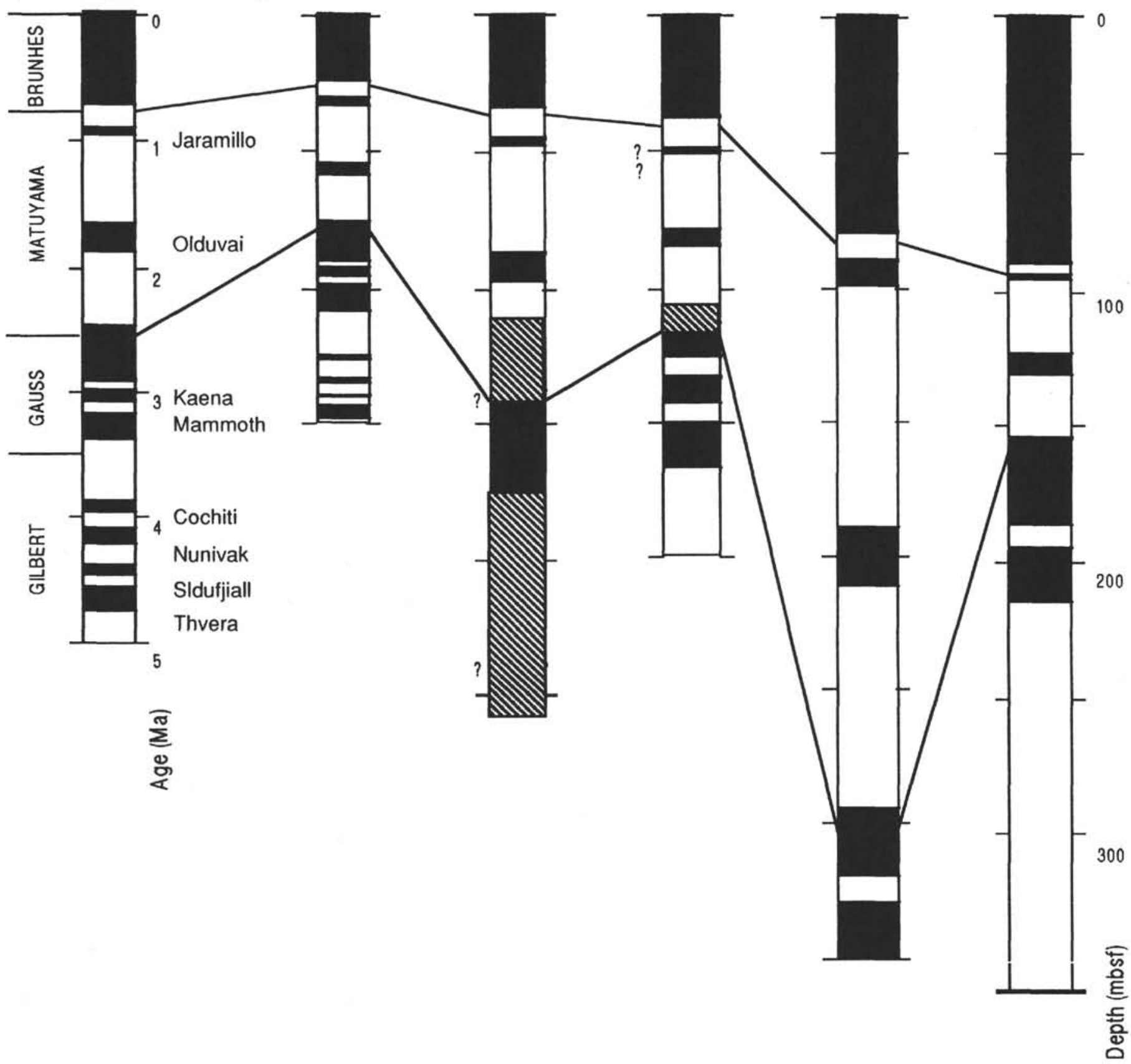

Figure 3. Polarity sequence obtained from Holes 794A, 795A, 797B, 798B, and 799A together with the polarity time scale by Berggren et al. (1985). Hatched regions at Sites 795 and 797 indicate mixed polarity.

the NRM decreased below $10^{-1} \mathrm{~mA} / \mathrm{m}$, and the susceptibility also followed a similar trend. As shown by the mineralogical data from the smear slide analysis of the sediments, a significant increase in the diatom content occurs at expense of the terrigenous sediments occurred at this depth.

The Brunhes/Matuyama boundary is located in the depth range 35-36 mbsf. However, this boundary is not sharp, but rather contains a very short excursion to normal polarity at about $85 \mathrm{~cm}$ below the initial appearance of reversed polarity (Fig. 4). This complex directional record could be representative of geomagnetic field behavior such as reported by Clement et al. (1982) in deep-sea sediments cores from the Pacific Ocean. However, it must be noted that the thermal demagnetization of orthogonal isothermal remanent magnetization (IRM) of two samples collected in the region of this boundary showed the presence of hematite, probably of secondary origin, as carrier of the remanence (Torii et al., this volume). 
Table 1. Depths of the polarity boundary observed at Sites 794, 795, 797, 798, and 799.

\begin{tabular}{lcccccc}
\hline Polarity boundary & Age (Ma) & Site 794 & Site 795 & Site 797 & Site 798 & Site 799 \\
\hline Matuyama/Brunhes & 0.73 & 24.6 & 35.0 & 38.3 & 79.5 & 90.0 \\
Jaramillo/Matuyama & 0.90 & 31.1 & 46.0 & $49.3 ?$ & 90.0 & 94.0 \\
Matuyama/Jaramillo & 0.98 & 34.1 & 48.6 & $51.3 ?$ & 99.5 & 96.0 \\
Olduvai/Matuyama & 1.66 & 54.6 & 87.0 & 78.6 & 190.0 & 123.5 \\
Matuyama/Olduvai & 1.88 & 58.8 & 97.2 & 84.6 & 212.0 & 131.5 \\
Gauss/Matuyama & 2.47 & 75.4 & $137.9 ?$ & $113.4 ?$ & 295.0 & 155.0 \\
Kaena/Gauss & 2.92 & 89.8 & $\ldots$ & 126.0 & 320.0 & 187.0 \\
Gauss/Kaena & 2.99 & 92.3 & $\ldots$ & 133.8 & 330.0 & $\ldots$ \\
Mammoth/Gauss & 3.08 & 95.5 & $\ldots$ & 143.6 & 410.0 & $\ldots$ \\
Gauss/Mammoth & 3.18 & 98.8 & $\ldots$. & 150.8 & 420.0 & $\ldots$ \\
Gilver/Gauss & 3.40 & 108.2 & $239.0 ?$ & 167.8 & $\ldots$ & 215.0 \\
Cochiti/Gilbert & 3.97 & 126.7 & & & & \\
Gilber/Cochiti & 4.10 & 133.8 & & & & \\
Nunivak/Gilbert & 4.34 & 135.9 & & & & \\
Gilber/Nunivak & 4.24 & 135.9 & & & & \\
SIdufjlal//Gilbert & 4.40 & 139.9 & & & & \\
Gilber/SIdufflall & 4.47 & 140.4 & & & & \\
Thvera/Gilbert & 4.57 & 143.8 & & & & \\
Gilber/Thvera & 4.77 & 148.5 & & & & \\
\hline
\end{tabular}

\section{SITE 797}

Site 797 is located at $38.616^{\circ} \mathrm{N}, 134.536^{\circ} \mathrm{E}$ in the southwestern Yamato Basin. Nineteen APC cores and 34 XCB cores were drilled at Hole 797B from the seafloor to a depth of $495.7 \mathrm{~m}$. A great effort was made to resolve the magnetostratigraphy of the entire recovered section, but a reliable polarity pattern was found only in the upper $170 \mathrm{~m}$ of the section which include the silty clay and clay of lithostrastratigraphic Unit I (10-119.9 m) and the diatomaceous ooze and clay of Unit II (119.9-224 m). Shipboard whole-core measurements of the APC cores revealed rust contamination; the top of the cores were identified by spikes in both the intensity of NRM and the magnetic susceptibility with a downcore decreasing trend. It is not clear whether the rust contamination affected the whole-core measurements of some intervals which exhibited scattered NRM directions.

As in the previous sites, the results that we present here are mainly confined to the APC cores. Diatomaceous ooze of Unit II is heavily bioturbated and mottled, and probably not suitable for paleomagnetic study. The magnetic susceptibility (a measure of the ferromagnetic content of the sediments) exhibited values lower than at previous sites. The IRM (magnetizing field of $0.5 \mathrm{~T}$ ) exhibited a decreasing trend downcore with minimum values at about $170 \mathrm{mbsf}$ (Fig. 5). An opposite trend was observed after AF demagnetization of IRM with a peak-field of $55 \mathrm{mT}$ (Fig. 5), indicating an increase of coercivity with depth.

Shore-based AF demagnetization was carried out on 171 discrete samples collected from Hole 797B. The weak intensity of NRM did not allow identification of a stable endpoint on the orthogonal plots especially for the samples measured with the spinner magnetometer at IGM (Fig. 6). Moreover, the magnetization is not always stable to $\mathrm{AF}$ (see Fig. 2).

Whole-core measurements provided a polarity pattern not always obvious. It is well defined in the upper $38 \mathrm{~m}$ of this section, but below this depth some intervals are characterized by scattered directions especially in the intervals which include the Brunhes/Matuyama, the Matuyama/Gauss and the Gauss/Gilbert boundaries. This scattering obscured the Jaramillo subchron which cannot be easily identified. Demagnetization of two discrete samples between 49.3 and $50.3 \mathrm{mbsf}$ exhibited a normal polarity that could be representative of this subchron. Even discrete samples studies did not help to define a polarity pattern between 102.4 and 113.4 mbsf. This interval belongs to the lithostratigraphic subunit $1 \mathrm{~B}$ which is characterized by silty clay and clay with increasing diatom content and bioturbation and by a decrease in the occurrence of ash layers with respect to the upper part of Unit 1 (Tamaki, Pisciotto, Allan, et al. 1990). Despite this complexly magnetized interval, magnetic reversal sequence of the upper $170 \mathrm{~m}$ can be reasonably correlated with the portion of the GPTS spanning the Brunhes, Matuyama, and Gauss chrons as shown in Figure 3.
The polarity pattern observed in the interval containing the Brunhes/Matuyama boundary is characterized by ambiguous results with several apparent changes of polarity of NRM occurring for several meters. Discrete samples collected from each of these "polarity zones" were accurately studied and the results change the picture obtained from the whole-core measurements. Several intervals which exhibited normal polarity NRM were found to be strongly overprinted and it was not possible to isolate the primary magnetization of the sediment. According to these results, the Brunhes/Matuyama boundary, which, on the basis of the whole-core measurements, was assigned at a depth of about $45 \mathrm{mbsf}$, was moved up to $38.3 \mathrm{mbsf}$. The magnetic mineralogy of closely spaced samples which exhibited different polarity was investigated by the Lowrie-Fuller test and thermal demagnetization of orthogonal IRM (Lowrie 1990). The results reported in the paper of Torii et al. (this volume) did not exhibit a significantly different magnetic mineralogy.

\section{SITE 798}

Site 798 is located in a small fault-bounded basin on top of Oki Ridge in the southeastern portion of the Yamato Basin $\left(37.04^{\circ} \mathrm{N}, 134.80^{\circ} \mathrm{E}\right)$. Three holes were drilled at Site 798. Holes 798A and 798C were drilled using the APC piston core to depths of 143.3 and 120.1 mbsf. Hole 798B was drilled using a combination of APC and XCB techniques to 517.9 mbsf. The age of the sedimentary succession ranges from late Quaternary to late early Pliocene. No major hiatuses have been identified.

The sedimentary sequence recovered at Site 798 consists of $514 \mathrm{~m}$ of clay, silty clay, diatomaceous clay to diatom ooze, foraminifer- and nannofossil-bearing biosiliceous sediments, and siliceous claystone. The sedimentary column at Site 798 was divided into three lithologic units based on composition, sedimentary structures, and mineralogy. Unit I $(0-220 \mathrm{mbs})$ is composed of clay, silty clay, diatomaceous clay, and diatom ooze with common foraminifers and calcareous nannofossils. This unit displays well-defined decimeter- to meter-scale rhythmic interbeds of dark-colored, laminated sediments that alternate with light-colored, homogeneous to intensely bioturbated intervals. Unit II $(220-455 \mathrm{mbsf})$ is made up of moderately indurated, diatomaceous clay interbedded with diatom ooze and silty clay. Unit III (455-518 mbsf) is composed of siliceous claystone and claystone with glauconitic and quartz sands in the lower $30 \mathrm{~m}$.

APC cores from Site 798 carry a very stable NRM in which secondary components of the remanence can be easily removed by alternating field demagnetizations to $10 \mathrm{mT}$. The stable directions of the remanence carried by the three APC cores give very consistent results except a $10 \mathrm{~m}$ interval just above the Brunhes/Matuyama polarity transition. In this interval, the scatter of NRM directions is much larger and the intensity of the magnetization is more than an order of magnitude lower than above and below the transition interval. In all three cores, geomagnetic field transitions at the Brunhes/Matuyama boundary and the stratigraphic limits of the Jaramillo event are clearly recorded as shown in Figure 7 . The intensity of the magnetization is about $10 \mathrm{~mA} / \mathrm{m}$ at the top of the sediment cores and decreases with depth to about $1 \mathrm{~mA} / \mathrm{m}$ at the bottom of the APC cores. In contrast, the initial magnetic susceptibility is nearly constant throughout the entire section of the APC cores (see Fig. 7). It is worth noting that the interval of $65-75 \mathrm{mbsf}$, where the intensity of the magnetization is much lower than that above and below does not show any detectable decrease of the susceptibility.

The variation of the direction of magnetization during the field reversal at the onset and the termination of the Jaramillo event is very sharp in the variations of declination and the inclination. However, the directional changes at the Brunhes/Matuyama boundary are quite complicated (Fig. 4). It is not clear that this complicated pattern reflects actual geomagnetic field variations, instability of the magnetization, or noise in the measurements. The low intensity of the magnetization associated with the scattered NRM directions can be reasonably accounted in either case. 

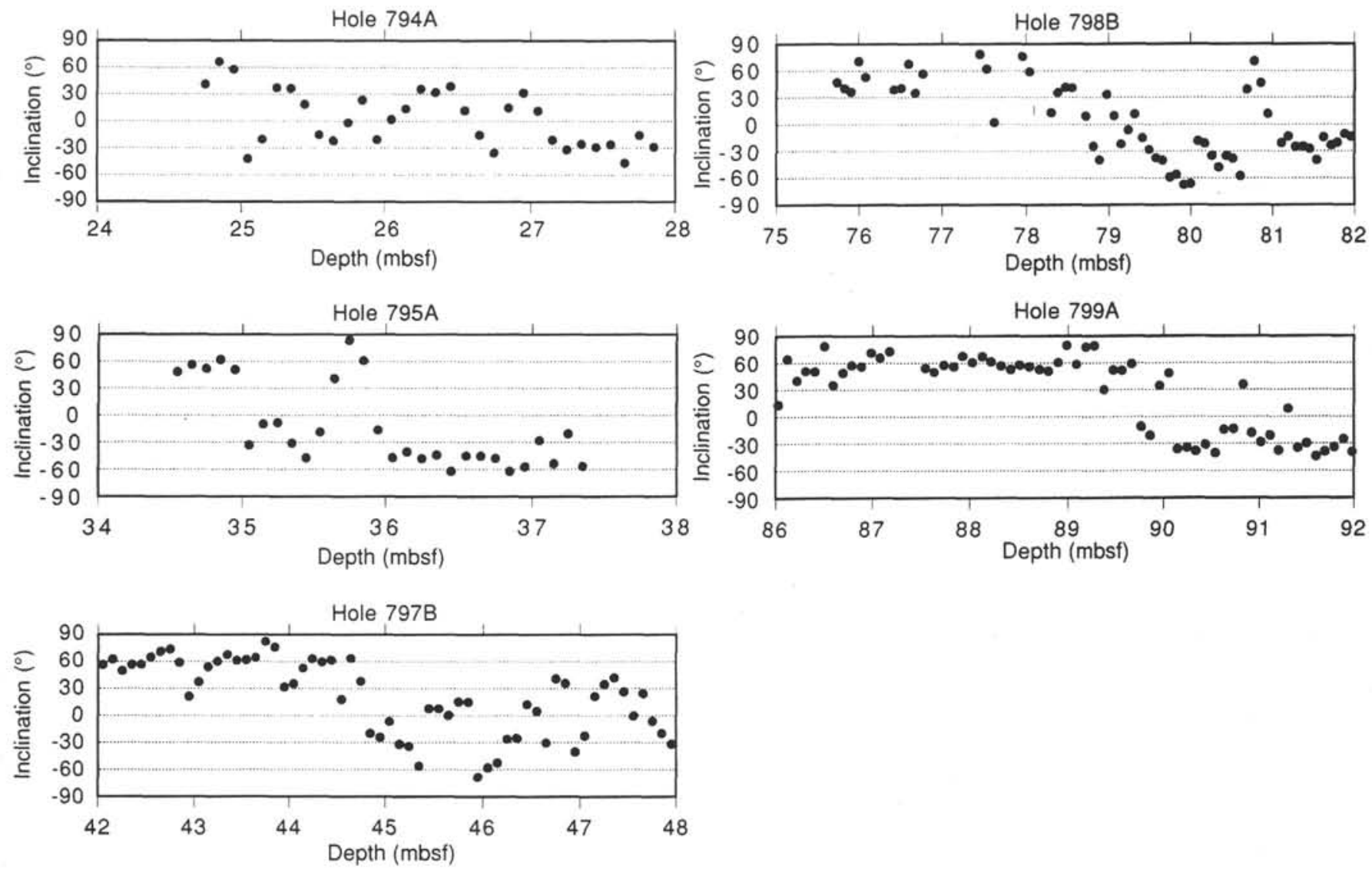

Figure 4. Variation of the observed inclination at the Matuyama/Brunhes boundary.

Observed variations of the NRM inclination and the intensity of the XCB cores from Hole 798B are shown in Figure 8. Scatter of the NRM inclinations changes at the boundary of the lithological units ( $220 \mathrm{mbsf}$ ). Above the boundary, NRM inclinations give a consistent result and clearly show the polarity changes at the onset and the termination of the Olduvai event at the depths of 190 and 212 mbsf, respectively. The intensity of the magnetization in this interval is comparable to that of the upper APC cores and higher than $1 \mathrm{~mA} / \mathrm{m}$. On the other hand, the NRM inclinations below this boundary are more scattered and the intensity is generally less than $1 \mathrm{~mA} / \mathrm{m}$. The Matuyama/Gauss boundary probably occurred at $295 \mathrm{mbsf}$ with dominantly positive inclination values below this level likely indicating normal polarity extending to the bottom of Hole 798B. Sedimentation rate at Site 798 implied by this interpretation seems fairly constant from the top to the depth of the Matuyama/Gauss boundary $(2.47 \mathrm{Ma})$ with the rate exceeding $100 \mathrm{~m} / \mathrm{m}$.y. Below this boundary, the sedimentation rate may have been higher if the interpretation that the bottom of Hole 798B ( $520 \mathrm{mbsf}$ ) is still in the Gauss chron is correct.

\section{SITE 799}

Site 799 is located in the southern Kita-Yamano Trough $\left(39^{\circ} 22^{\prime} \mathrm{N}\right.$, $133^{\circ} 87^{\prime} \mathrm{E}$ ), a narrow topographic and structural depression that splits the larger Yamato Rise in the south central Sea of Japan. At Site 799, three holes (Holes 799A, 799B, and 799C) were drilled, in which Hole 799C was drilled solely for the purpose of testing the SCM (sonic core monitor) tools. In Hole 799A, APC cores were taken to $184.1 \mathrm{mbsf}$, and then, XCB cores were taken down to $468.7 \mathrm{mbsf}$. Sixty-seven RCB (rotary core barrel) cores were taken for the section spanning from 450 to $1084 \mathrm{mbsf}$ from Hole 799B.

Dominant lithologies within the $468.7 \mathrm{~m}$ of upper Miocene to Holocene sediments cored in Hole 799A include biosiliceous sediments and fine-grained detrital sediments intercalated with carbonate-rich intervals. The Hole 799B sequence consists of $633 \mathrm{~m}$ of lower Miocene through upper Miocene, diagenetically altered, biosiliceous sediments. The sediment column at Site 799 was divided into five lithologic units. Unit I ( $0-170 \mathrm{mbsf})$ is composed of diatomaceous clay and ooze, diatomaceous clay mixed sediments, etc. Unit II (170-457 mbsf) is made up of diatomaceous ooze, clay diatomaceous ooze etc. Unit III (457-800 mbsf) is composed of siliceous claystone and porcellanite. Unit IV (800-1020 mbsf) comprises finely laminated to thinly bedded siliceous claystone and porcellanite. Unit $\mathrm{V}(1020-1084 \mathrm{mbsf})$ is composed of siliceous claystone and claystone with silt. Soft-sediment deformation is a common feature within Unit I. Major intervals of deformed soft sediments are present between 10.0 and $11.2 \mathrm{mbsf}$, from 40.0 to $70.0 \mathrm{mbsf}$, and from 141.2 to 151.2 mbsf.

NRM carried by the APC cores from Hole 799A are stable, and the $180 \mathrm{~m}$ section of the APC cores record six polarity transitions: Brunhes/Matuyama, Jaramillo, Olduvai, and Matuyama/Gauss (Fig. 9). However, the soft-sediment deformation (slumping) apparently cause some spurious NRM directions. The normal polarity zone at the interval between 140 and 150 mbsf depth is caused by such a slump structure, which can be easily recognized from the recovered cores.

The intensity of NRM steadily decreases with depth from 10 $\mathrm{mA} / \mathrm{m}$ at the top to $0.1 \mathrm{~mA} / \mathrm{m}$ at the bottom of the APC core (184 mbsf), whereas the magnetic susceptibility is fairly constant throughout the entire section of the APC cores.

The Brunhes/Matuyama boundary is observed at a depth of 90 mbsf, which suggests a high sedimentation rate of more than 110 $\mathrm{m} / \mathrm{m}$.y. for the interval younger than this boundary. On the other hand, depths of the Jaramillo event, Olduvai event, and the Matuyama/Gauss boundary indicate that the sedimentation rate for the lower section of the APC cores is much lower with the values of about $40 \mathrm{~m} / \mathrm{m}$.y. 
A

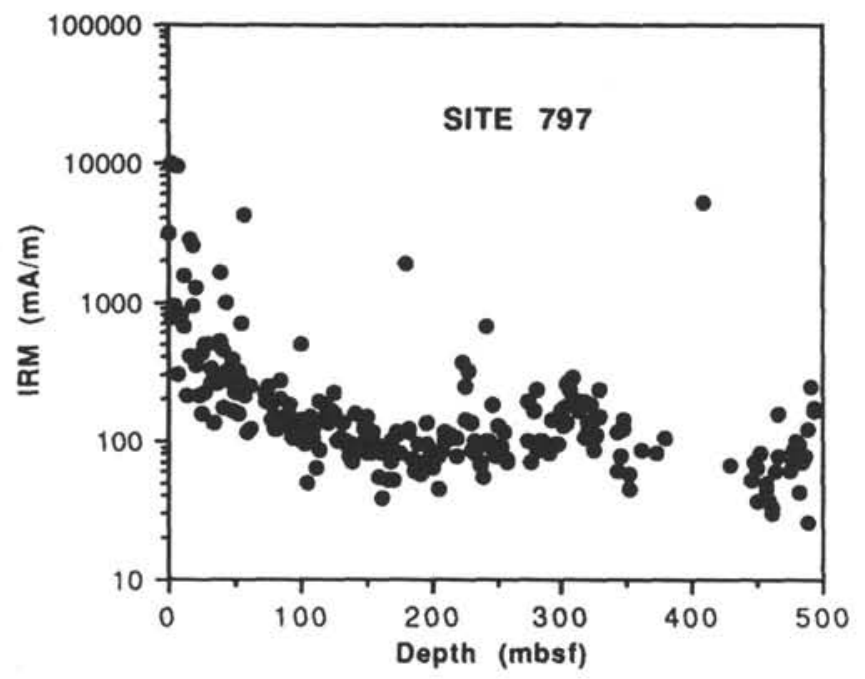

B

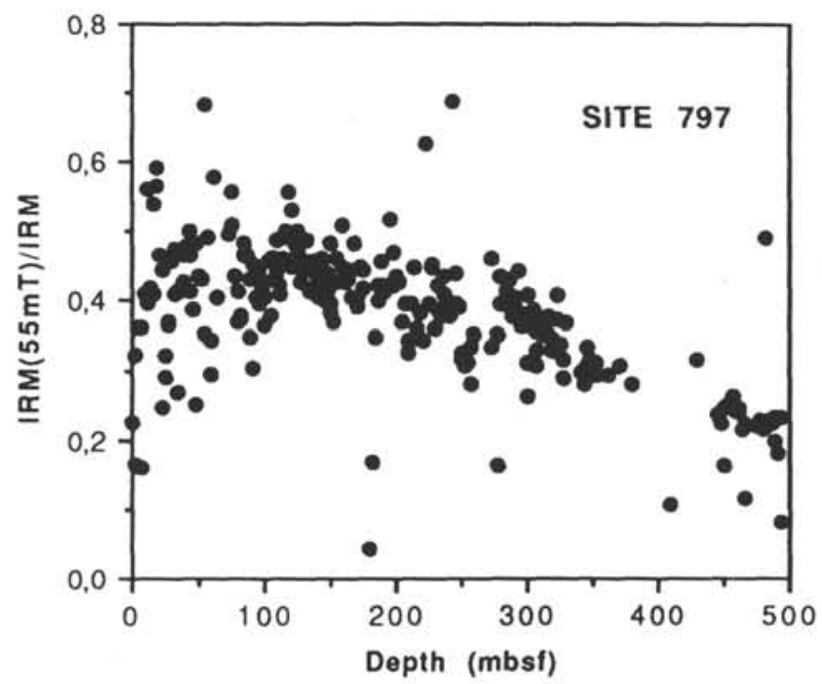

Figure 5. Depth plot of IRM (A) and percent of IRM (B) after the AF demagnetization with peak-field of $55 \mathrm{mT}$.

Inclination and intensity of NRM data for the XCB cores from Hole 799A are summarized in Figure 10. Scattered directional data correlate with the low intensity of the magnetization, as observed in Hole 798B. From the data, the Gauss/Gilbert and Gilbert/Chron 5 boundaries are tentatively assigned at depths of 225 mbsf and 394 mbsf, respectively. Other sub-events could not be assigned due to the scattered data. The intensity of the magnetization for this section is low with the values between 0.1 and $1 \mathrm{~mA} / \mathrm{m}$.

Results of the paleomagnetic measurements on the RCB cores recovered from Hole $799 \mathrm{~B}$ are summarized in Figure 11, where inclination, intensity of NRM, and susceptibility are shown. The observed inclination values for the entire $600 \mathrm{~m}$ interval of the sediment column are mostly positive, which is probably due to a viscous remanent magnetization overprint aligned with the present geomagnetic field. The low intensity of the magnetization of less than $0.1 \mathrm{~mA} / \mathrm{m}$ preclude the possibility to further study the remanence properties of the sediments. It is worth noting that the susceptibility of the sediments is comparable to the upper section of the sediments at Site 799.

\section{DISCUSSION}

Magnetostratigraphic data from the Japan Sea is summarized in Figure 3 , and the depths of the polarity boundaries are listed in Table 1. Because of the low intensity of the NRM, the pre-Gauss chron data are generally unreliable in most of the sites. The interpreted age-depth relations for Sites 794, 795, 797, 798, and 799 are displayed in Figure 12. It is evident that the sedimentation rate has been kept constant with a high value of $110 \mathrm{~m} / \mathrm{m}$.y. for the last $2.5 \mathrm{~m} . \mathrm{y}$. at Site 798 on the Oki ridge. The sedimentation rate seems to have been also constant at Site 794, although the rate is as low as $30 \mathrm{~m} / \mathrm{m}$.y. On the other hand, the Brunhes/Matuyama boundary at Site 799 is observed at the depth of $90 \mathrm{mbsf}$, suggesting a high sedimentation rate for the last $700,000 \mathrm{yr}$ at this site. But, before this time, the sedimentation rate had been much lower with a value of about $40 \mathrm{~m} / \mathrm{m}$.y. It is worth attempting to examine the cause of this abrupt change of the sedimentation rate. For this purpose the data at Site 797, which is located at the southern flank of the Yamato Rise, may be helpful. Unfortunately, the data at this site are not sufficient to discuss the change of the sedimentation rate. Sites 797 and 795 seem to have an intermediate sedimentation rate of around $50 \mathrm{~m} / \mathrm{m}$.y. for the last $2.5 \mathrm{~m}$.y. But, some ambiguity of the interpretation of the polarity boundary at these sites preclude further detailed study.

The importance of magnetostratigraphy as a tool in understanding the history of the Yamato Basin can be demonstrated by some observations about the thickness of the Olduvai event. According to our results, this subchron spans $4.2 \mathrm{~m}$ at Site 794, $6 \mathrm{~m}$ at Site 797, and $10.2 \mathrm{~m}$ at Site 795. Considering that this subchron (according to Berggren et al., 1985) spans $220,000 \mathrm{yr}$, from 1.66 to $1.88 \mathrm{Ma}$, it appears that the sedimentation rate in the Yamato Basin was reduced by more than $30 \%$ during this period at both the studied sites (from $30 \mathrm{~m} / \mathrm{m} . \mathrm{y}$. to $19 \mathrm{~m} / \mathrm{m} . \mathrm{y}$. at Site 794 , and from $43 \mathrm{~m} / \mathrm{m}$.y. to $27 \mathrm{~m} / \mathrm{m}$ y. at Site 797). On the other hand, at Site 795 , sediment accumulation was reduced from $57 \mathrm{~m} / \mathrm{m}$.y. to $46 \mathrm{~m} / \mathrm{m}$.y, about $18 \%$. Sedimentological evidence, based on the deposition of light and dark color bands, shows that the Japan Sea suffered periods of isolation and restricted circulation starting in the Late Pliocene. The above results may indicate that this isolation occurred during the Olduvai event and it was more marked in the Yamato Basin, i.e., in the southern part of the Japan Sea.

As discussed above, the quality of the magnetostratigraphic data is somewhat different among the sites in the Japan Sea, although the sediment lithologies of these sites are not significantly different. Sediment cores from Sites 794, 798, and 799 provide fairly good polarity records at least for the last $2.5 \mathrm{~m}$.y. On the other hand, the data from Sites 795 and 797 gave somewhat ambiguous results. Within each site, the top portion of the cores yields better results than the lower parts. The directional stability of the NRM carried by the sediments correlates with the intensity of the magnetization; the higher intensity samples tend to have better stability in the direction of NRM. For examining the cause of this variation, correlation between the intensity of the magnetization and the magnetic susceptibility may give an important clue. However, the relation seems different among the present sites. At Leg 127 sites (794, 795 and 797), it seems that the downward decrease of the intensity of the magnetization well correlate with the decrease of the susceptibility, whereas the susceptibility is constant throughout the sedimentary sections at Leg 128 sites (Sites 798 and 799, see Figs. 7, 9, and 11), although the intensity of the NRM decreases with depth. Hence, interpretation of the effect is not straightforward. Two possible interpretations are given below.

Both NRM and magnetic susceptibility showed a downcore decrease at Sites 794, 795, and 797. The IRM studied at Site 797 


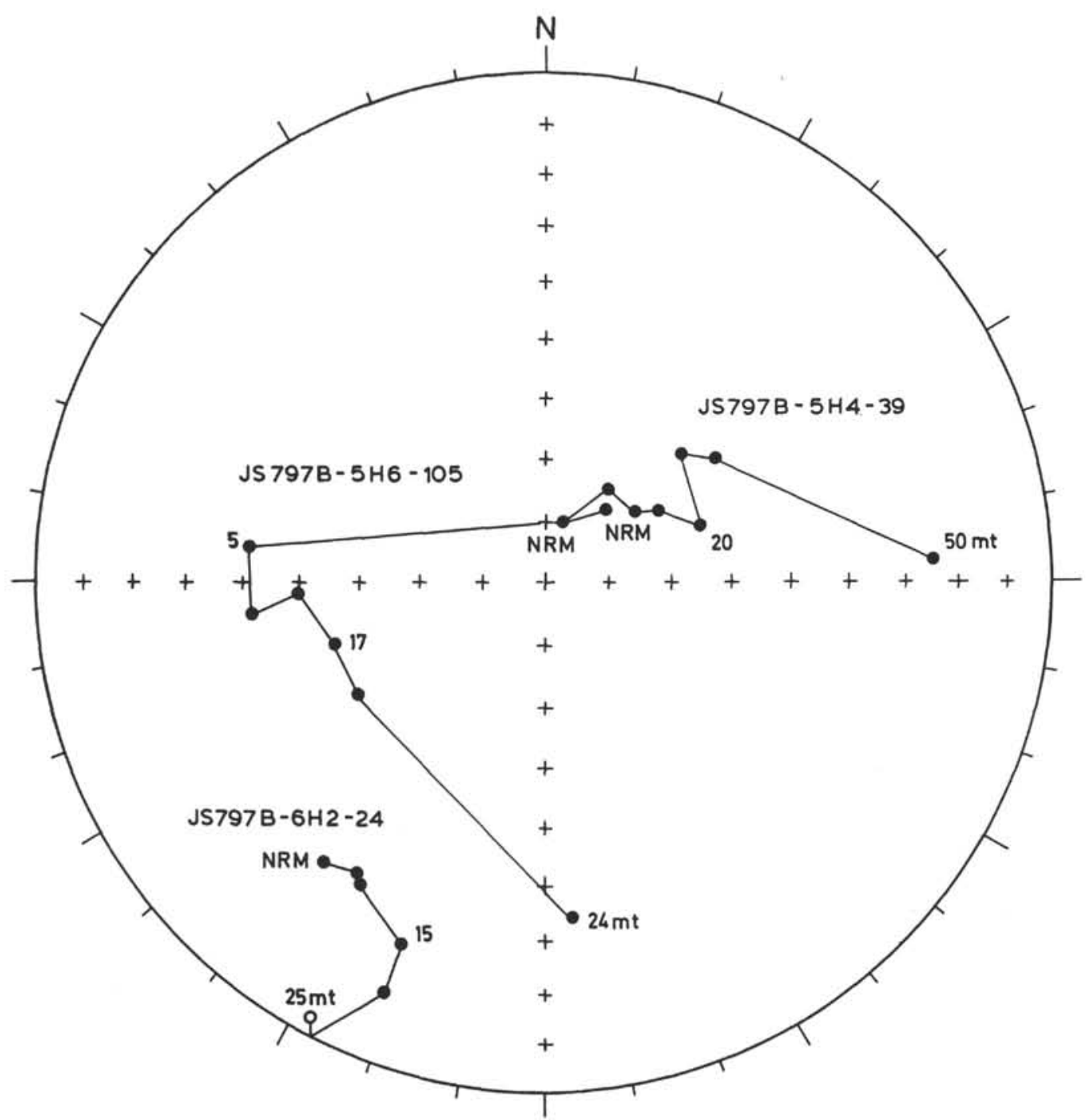

Figure 6. Equal area plot of the demagnetization curves for some samples from Hole 797B. Closed (open) dots for lower (upper) hemisphere.

exhibited the same trend, whereas the coercivity increased with depth (Fig. 5). Progressive downcore dissolution of detrital titanomagnetite has been reported by several authors in deep sea sediments and it has been related to diagenesis of magnetite to non-ferrimagnetic forms in suboxic/anoxic environments (Karlin and Levi, 1983, 1985; Canfield and Berner, 1987; Froelich et al., 1979; Karlin, 1990). Sulfate reduction due to bacterial degradation of organic matter has been clearly recognized in the Japan Sea (Tamaki, Pisciotto, Allan, et al. 1990). The weak magnetization of the sediments due to diagenetic loss and/or decrease in the grain size of magnetite could explain the low quality of the polarity zonation recorded in the lower part of the studied sections and in some intervals at Sites 795 and 797.

Site 794 yielded a much better magnetic polarity record, probably due to more constant sedimentological conditions. The accumulation rate calculated for the Pliocene-Pleistocene on the basis of the polarity boundaries reported in Figure 12 shows that the sedimentation rate at Site 794 was quite constant at least for the last 5 m.y. In contrast, Sites 795 and 797 exhibited some fluctuations with a marked increase in the sedimentation rate in the middle Pliocene. The differences between the two sites (795 and 797) and Site 794 may indicate that the degradation of the primary magnetite is not the same at all the sites and is affected by the fluctuation of the sedimentation rate.
In contrast to the above three sites, the magnetic susceptibility is almost constant throughout the sedimentary columns at Sites 798 and 799. The bottom part of Hole 799B has a magnetic susceptibility value comparable to the top part of Hole 799A (compare Figs. 9 and 11). Figure 7 indicates a slight decrease of the susceptibility with depth in Hole 798A. But, the magnitude of the decrease for the $150 \mathrm{~m}$ interval is less than a factor of two, whereas the decrease in intensity for the same interval is more than an order of magnitude. Figure 7 also indicates that the short period variations of the intensity of the magnetization do not correlate with those of the susceptibility as evident at the interval between 70 and 80 mbsf. Figures 8,10 , and 11 also indicate the constant nature of the susceptibility throughout the sedimentary section at Site 799.

It is also important to determine whether the decrease of the NRM intensity correlates with depth or age in these cores. This can be demonstrated from the comparison of the intensity variations in Holes 794A and 798A. The intensity of NRM in the top $10 \mathrm{~m}$ of Hole 794A exceeds $10 \mathrm{~mA} / \mathrm{m}$ and sharply decreases to a few $\mathrm{mA} / \mathrm{m}$ at the depth of $30 \mathrm{mbsf}$ just before the Matuyama/Brunhes polarity transition. The NRM intensity slowly decreases down to the onset of the Olduvai event at the depth of $60 \mathrm{mbsf}$, and then the NRM intensity decreases to values mostly less than $1 \mathrm{~mA} / \mathrm{m}$. On the other hand, the NRM 

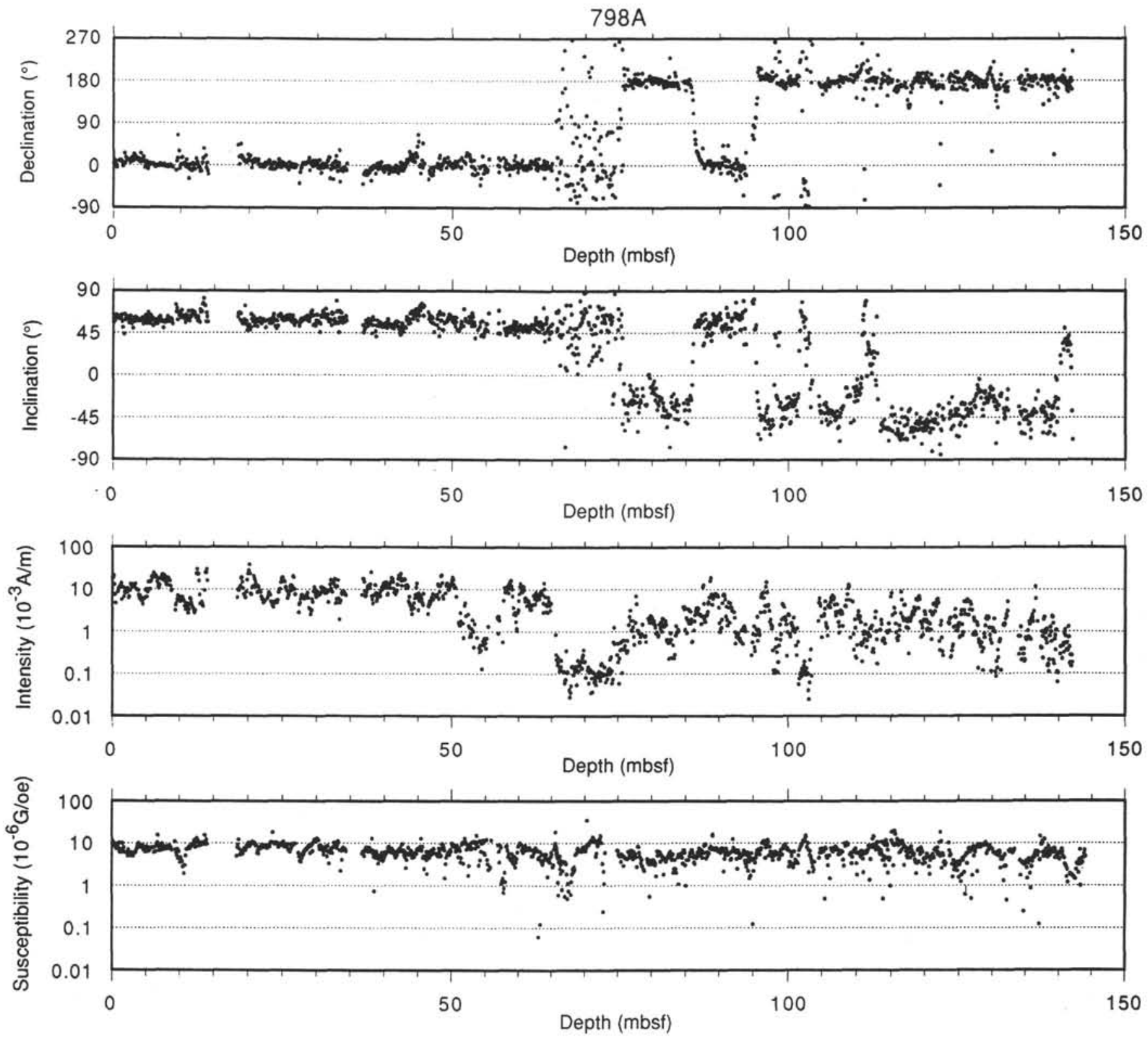

Figure 7. Depth plot of the variation of declination, inclination, intensity, and susceptibility observed in the APC cores from Hole 798A.

intensity of the sediments from Hole 798A retains a value higher than $10 \mathrm{~mA} / \mathrm{m}$ for the top $50 \mathrm{~m}$, which is still within the Brunhes epoch. Deeper than 100 mbsf, the average NRM intensity is still greater than $1 \mathrm{~mA} / \mathrm{m}$. As shown in Figure 8, the average intensity decreases to less than $1 \mathrm{~mA} / \mathrm{m}$ below the onset of the Olduvai event at the depth of about 250 mbsf. A similar trend is also observed in the sediments at Site 799, where the sedimentation rate below the Brunhes/Matuyama boundary is much lower than that at Site 798. These observations suggest that the variation of the intensity of the magnetization of the sediments from the Japan Sea correlate with the age of the sediments.

The apparent lack of dependence of the NRM intensity on magnetic susceptibility and the correlation of the NRM intensity with age may constrain the cause of these variations. A change of the concentration of the magnetic minerals in sediments can be precluded as a cause, since the magnetic susceptibility does not change. One possibility is the change of grain size or chemical composition of the magnetic minerals. The variation of the chemistry of sea water with age may affect these factors. However, it is difficult to imagine a sedimentological environment which causes the changes of these factors without affecting the magnetic susceptibility, since the grain size and the chemical composition both affect the bulk magnetic susceptibility even if concentration of the magnetic minerals is constant. The simplest interpretation is, therefore, that the variations of the NRM intensity record changes of geomagnetic field strength with time. However, a variation of two orders of magnitude within a few million years is inconsistent with the presently available paleomagnetic data. Some unknown intensification effect of the sediment magnetization to the ambient intensity of geomagnetic field can be an explanation of the intensity variation observed in the Japan Sea.

The intensity of the magnetization of the sediments, which give scattered directions, is generally less than $1 \mathrm{~mA} / \mathrm{m}$. These samples are also unstable to AF demagnetization. Hence, the noise of the magnetometer may be a cause of the correlation between the intensity and the directional dispersion of the magnetization. As another possibility, the instability exhibited by the sediments during AF cleaning could be related to the anisotropic nature of magnetic minerals which carry the 

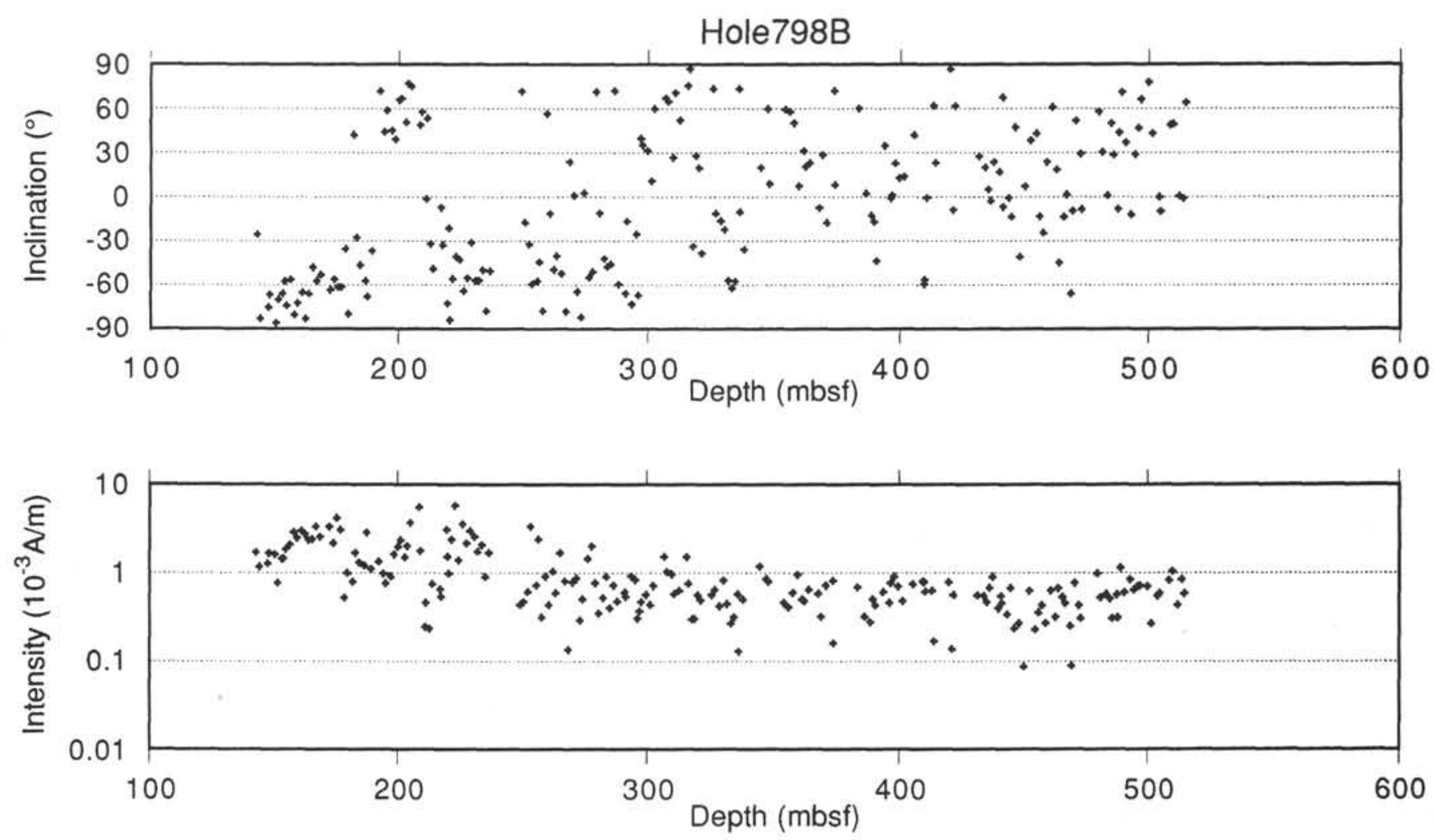

Figure 8. Depth plot of inclination and intensity observed in the XCB cores from Hole 798B.

NRM. Thermal demagnetization of orthogonal IRM (Lowrie, 1990) showed the presence of pyrrhotite in the sediments (Torii et al., this volume) that could be responsible for the observed behavior.

Complicated behavior of the geomagnetic field during the Matuyama/Brunhes polarity transition has been reported previously (Fuller et al., 1979; Clement et al., 1982; Okada and Niitsuma, 1989). Reliable polarity transitions observed in the present sites are Brunhes/Matuyama transition, Jaramillo and Olduvai events, and Matuyama/Gauss boundary. Among these, the Matuyama/Brunhes boundary is much more complicated than other polarity boundaries. Since this complexity of the polarity transition behavior is observed in sediment cores with different sedimentation rates and these core indicate the contrast between the $\mathrm{Ma}-$ tuyama/Brunhes boundary and other polarity boundaries, it is suggested that the complexly changing NRM directions actually reflects the variation of the geomagnetic field during this polarity transition.

\section{REFERENCES}

Berggren, W. A., Kent, D. V., and Van Couvering, J. A., 1985. The Neogene: Part 2. Neogene geochronology and chronostratigraphy. In Snelling, N. J. (Ed.), Geochronology and the Geologic Record. Mem.-Geol. Soc. London, 10:211-260.

Canfield, D. E., and Berner, R. A., 1987. Dissolution and pyritization of magnetite in anoxic marine sediments. Geochim. Cosmochim. Acta., $51: 645-659$.

Channell, J.E.T., Hawthorne, T., and Torii, M., 1990. Contrasting magnetic properties in Leg 107 sediments: preservation and alteration of titanomagnetite at adjacent sites. In Kastens, K. A., Mascle, J., et al., Proc. ODP, Sci. Results, 107: College Station, TX (Ocean Drilling Program), 113-128.
Clement, B. M., Kent, D. V., and Opdyke, N. D., 1982. Brunhes-Matuyama polarity transition in three deep-sea cores. Philos. Trans. R. Soc. London A, 306:113-119.

Froelich, P. N., Klinkhammer, G. P., Bender, M. L., Luedtke, N. A., Heath, G. R., Cullen, D., and Dauphin, P., 1979. Early oxidation of organic matter in pelagic sediments of the eastern equatorial Atlantic: suboxic diagenesis. Geochim. Cosmochim. Acta, 43:1075-1090.

Fuller, M., Williams, I., and Hoffman, K. A., 1979. Paleomagnetic records of geomagnetic field reversals and the morphology of the transition fields. Rev. Geophys. Space Phys., 17:179-203.

Karlin, R., 1990. Magnetite diagenesis in marine sediments from the Oregon continental margin. J. Geophys. Res., 95:4405-4419.

Karlin, R., and Levi, S., 1983. Diagenesis of magnetic minerals in Recent haemipelagic sediments. Nature, 303:327-330.

1985. Geochemical and sedimentological control of the magnetic properties of hemipelagic sediments. J. Geophys. Res., 90:10373-10392.

Lowrie, W., 1990. Identification of ferromagnetic minerals in a rock by coercivity and unblocking temperature properties. Geophys. Res. Lett., 17:159-162.

Okada, M., and Niitsuma N., 1989. Detailed paleomagnetic records during the Brunhes-Matuyama geomagnetic reversal, and a direct determination of depth lag for magnetization in marine sediments. Phys. Earth Planet. Inter, 56:133-150.

Tamaki, K., Pisciotto K., Allan J., et al. 1990. Proc. ODP, Init. Repts., 127: College Station, TX (Ocean Drilling Program).

Date of initial receipt: 12 April 1991

Date of acceptance: 11 March 1992

Ms 127/128B-216 

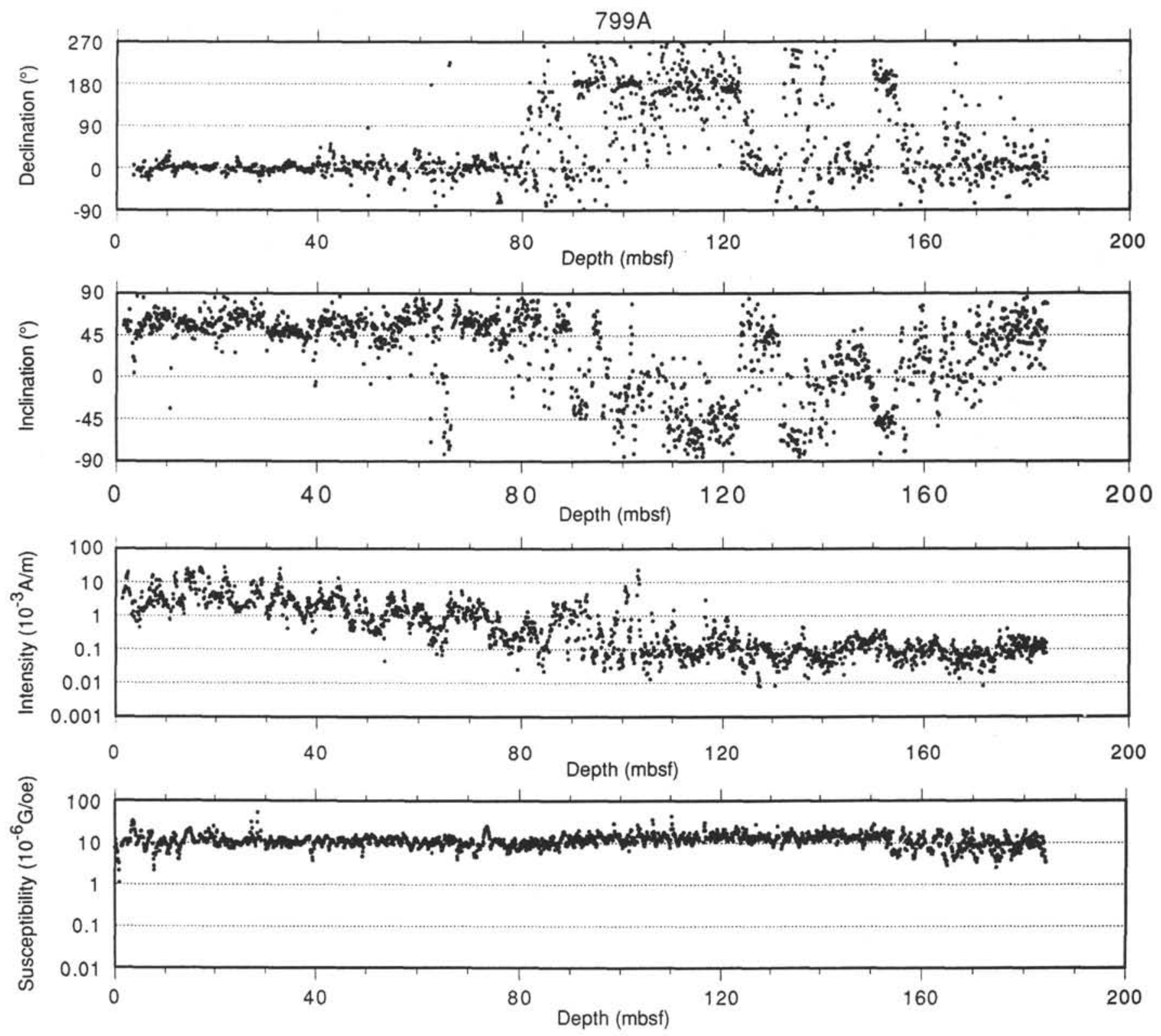

Figure 9. Depth plot of declination, inclination, intensity, and susceptibility observed in the APC cores from Hole 799A. 

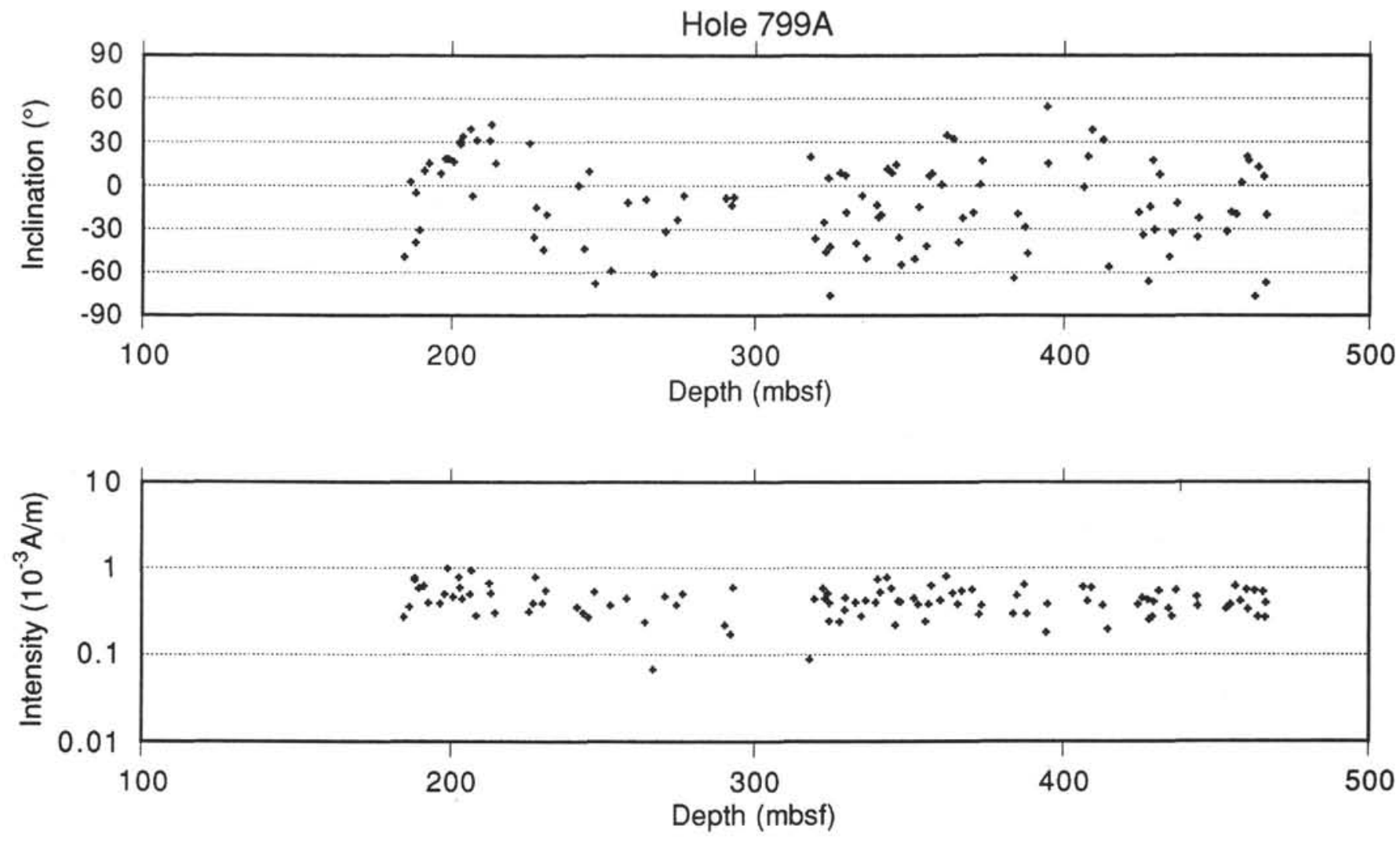

Figure 10. Depth plot of inclination and intensity observed in the XCB cores from Hole 799A. 

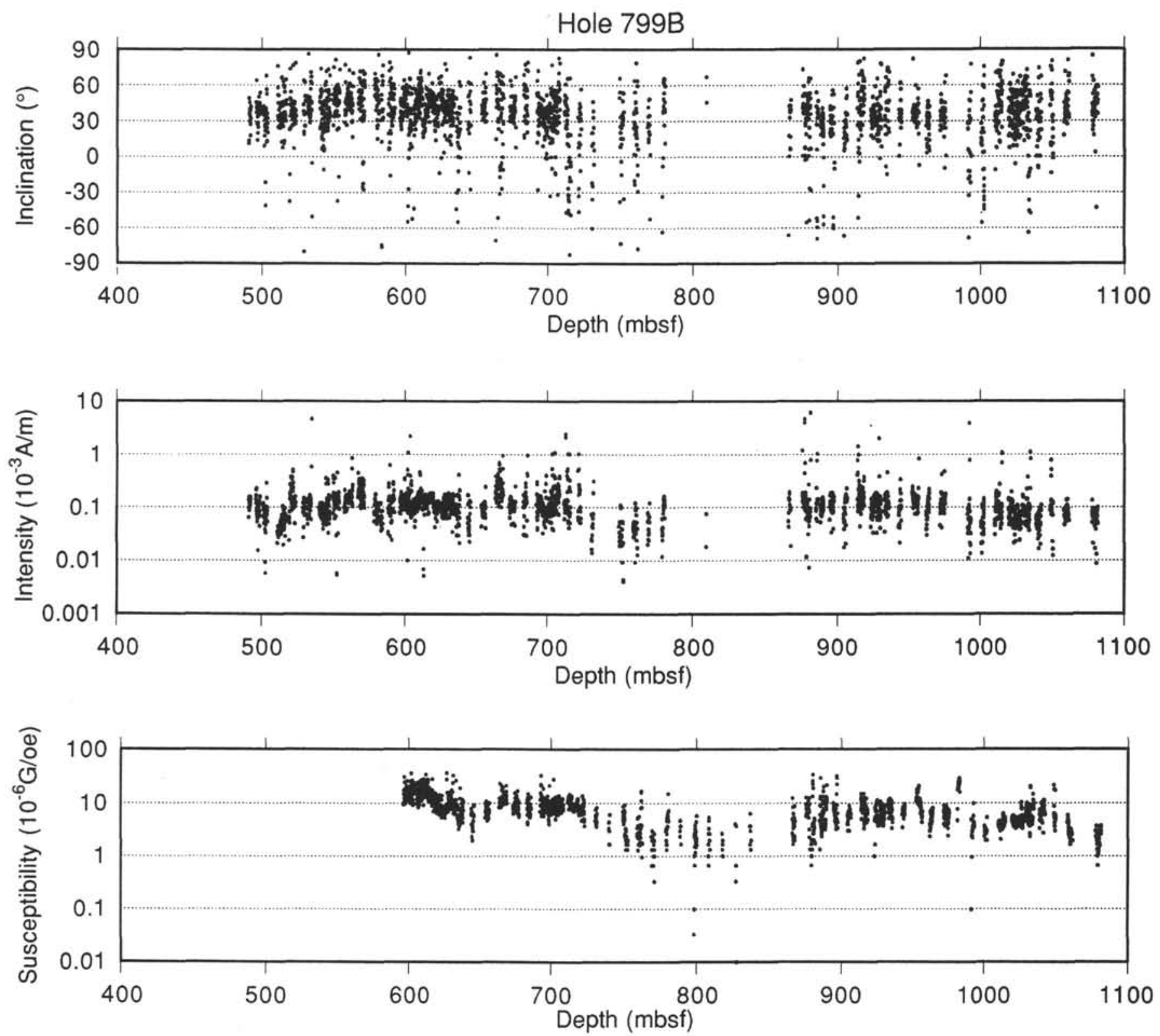

Figure 11. Depth plot of inclination, intensity, and susceptibility observed in the RCB cores from Hole 799B. 


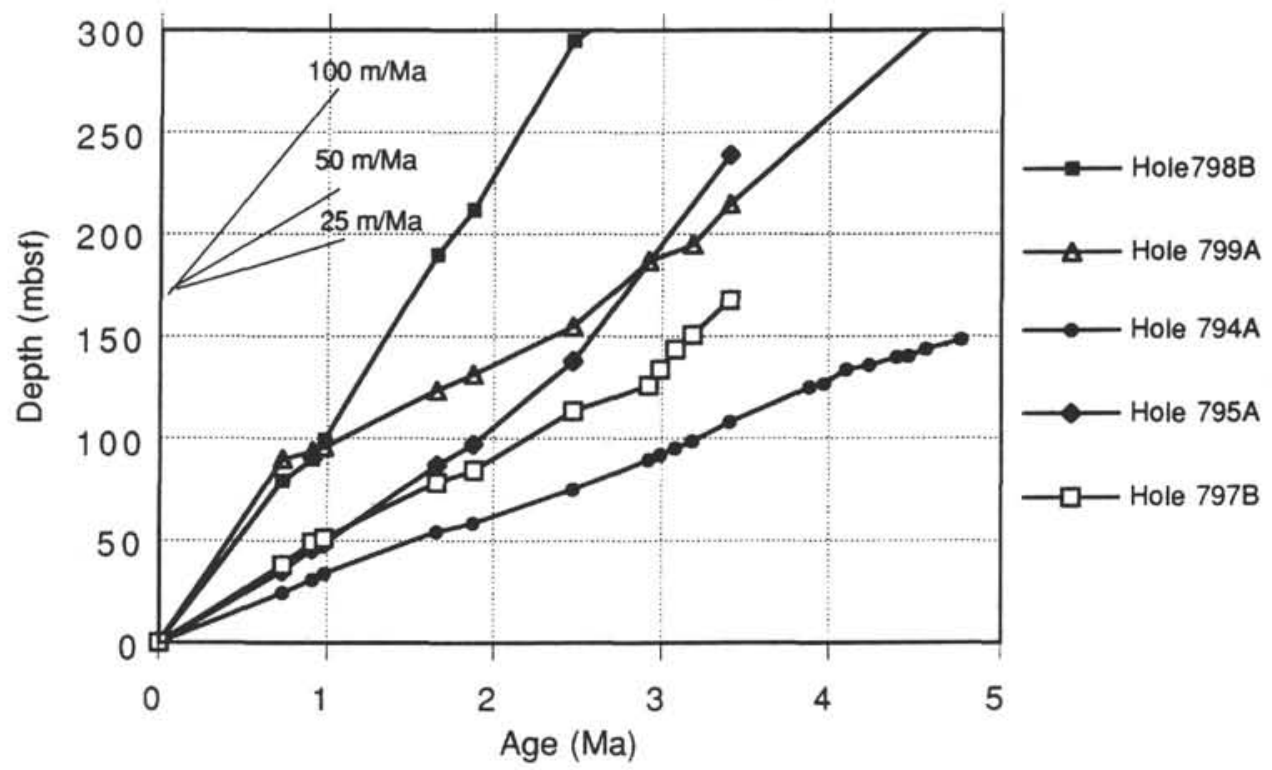

Figure 12. Age vs. depth relationship for Sites 794, 795, 797, 798, and 799. 